$12-2002$

\title{
Long-distance dispersal potential in a marine macrophyte
}

MC Harwell

Virginia Institute of Marine Science

R J. Orth

Virginia Institute of Marine Science

Follow this and additional works at: https://scholarworks.wm.edu/vimsarticles

Part of the Marine Biology Commons

\section{Recommended Citation}

Harwell, MC and Orth, R J., Long-distance dispersal potential in a marine macrophyte (2002). Ecology, 83(12), 3319-3330.

$10.2307 / 3072082$

This Article is brought to you for free and open access by the Virginia Institute of Marine Science at W\&M ScholarWorks. It has been accepted for inclusion in VIMS Articles by an authorized administrator of W\&M ScholarWorks. For more information, please contact scholarworks@wm.edu. 


\title{
LONG-DISTANCE DISPERSAL POTENTIAL IN A MARINE MACROPHYTE
}

\author{
Matthew C. Harwell ${ }^{1}$ And Robert J. Orth \\ Virginia Institute of Marine Science, College of William and Mary, Gloucester Point, Virginia 23062 USA
}

\begin{abstract}
Plant populations have long been noted to migrate faster than predicted based on their life history and seed dispersal characteristics (i.e., Reid's paradox of rapid plant migration). Although precise mechanisms to account for such phenomena are not fully known for all plant species, a combination of theoretical and empirically driven mechanisms often resolves this paradox. Here, we couple a series of direct and indirect field and laboratory exercises on one marine macrophyte, Zostera marina L. (eelgrass), to measured distances between new patches and established beds in order to elucidate the long-distance
\end{abstract} dispersal and colonization potential of this marine seagrass.

Detached, floating reproductive shoots with mature seeds were found to remain positively buoyant for up to $2 \mathrm{wk}$ and retain mature seeds for up to $3 \mathrm{wk}$ before release under laboratory conditions. Analysis of the detritus wrack along a remote shoreline found reproductive fragments with viable seeds up to $34 \mathrm{~km}$ from established, natural beds. Analysis of different regions of the Chesapeake Bay and coastal bays of the Delmarva Peninsula that once supported eelgrass populations, revealed natural patches at 13 sites ranging from 1 to $108 \mathrm{~km}$ from established populations. A combination of tidal currents and wind influences has the potential to move a passive particle at the surface (e.g., a floating reproductive fragment) up to $23 \mathrm{~km}$ in a 6-h tidal window suggesting that most unvegetated areas in this region that can support eelgrass are within the colonization potential envelope.

We suggest that, when combined with earlier work on seed dispersal ecology of this species, eelgrass has strong qualities for high colonization potential of new habitat. The finding of natural patches at such great distances from established beds when studied in the context of the dispersal mechanism (currents and wind) make the dispersal distances of this species one of the highest for angiosperms, comparable in scale to mangroves and coconuts. This new understanding of the dispersal dynamics of eelgrass is critical in the context of seagrass restoration in areas distant from established beds, maintenance of existing populations threatened by anthropogenic inputs of sediments and nutrients, and examining metapopulation concepts in seagrass ecology.

Key words: Chesapeake Bay, USA; eelgrass; long-distance dispersal; marine macrophyte; seagrass ecology; spatial ecology; Zostera marina.

\section{INTRODUCTION}

The distribution and abundance of plants across a landscape are driven, at least initially, by seed dispersal processes. The spread of existing populations and the potential for new population formation are determined by mechanisms that control seed dispersal, either as a function of escaping higher mortality near the parent plant (the escape hypothesis), colonizing disturbed, noncompetitive habitats (the colonization hypothesis), and/or finding distinct microhabitats (the directed dispersal hypothesis) (Howe and Smallwood 1982). These processes are important for issues of habitat fragmentation (Shafer 1995), disturbance ecology (Moloney and Levin 1996), patch dynamics, and mosaic patterns in local and landscape ecology (Pulliam and Danielson 1991). Seed dispersal can occur in discrete steps that can significantly alter the position of a dispersing prop-

Manuscript received 20 May 2002; accepted 20 May 2002 (manuscript originally submitted 16 February 2000).

${ }^{1}$ Present address: A. R. M. Loxahatchee National Wildlife Refuge, 10216 Lee Road, Boynton Beach, Florida 33437 USA. E-mail: matthew_harwell@fws.gov agule from its parent plant. Chambers and MacMahon (1994) identified two categories of seed dispersal depending on when dispersal occurs. Phase I dispersal identifies the primary dispersal of a seed from the parent plant to an initial substrate, while Phase II identifies secondary dispersal of a seed, either horizontal or vertical, subsequent to the seed reaching the substrate (Chambers and MacMahon 1994). The final position of a propagule will ultimately depend on the relative influence of each of these phases acting upon that propagule.

Processes controlling dispersal can be mediated by biological (e.g., zoochory) and/or physical (e.g., anemochory, hydrochory) factors (Howe and Smallwood 1982, van der Pijl 1982). For example, in some plants with known adaptations for wind dispersal, seeds can subsequently be eaten and excreted by, or inadvertently attached to, an animal and dropped some distance from their initial location (Chambers and MacMahon 1994, Wilkinson 1997). Seed dispersal distances for many plants are generally quite small $(<10 \mathrm{~m})$, with ranges for animal-dispersed seeds greater than those for winddispersed seeds (Wilkinson 1997, 1999; but see Cham- 
TABLE 1. Vectors and scales of natural dispersal of eelgrass through propagation.

\begin{tabular}{|c|c|c|}
\hline Vector & Scale & Source \\
\hline \multicolumn{3}{|l|}{ Pollen } \\
\hline Viability & $<8 \mathrm{~h}$ & Cox et al. (1992), Ruckelshaus (1994) \\
\hline Dispersal & $15 \mathrm{~m}$ & Ruckelshaus (1996) \\
\hline \multicolumn{3}{|l|}{ Seed } \\
\hline Settling velocity & $5.96 \mathrm{~cm} / \mathrm{s}$ & Orth et al. (1994) \\
\hline Direct release $\dagger$ & $<5 \mathrm{~m} ; 14 \mathrm{~m} \max$ & Orth et al. (1994) \\
\hline Local dispersal & $\geq 20 \mathrm{~m} ;<50 \mathrm{~m}$ & Ruckelshaus (1996) \\
\hline Surface tension $\S$ & $<200 \mathrm{~m}$ & Churchill et al. (1985) \\
\hline Fish/waterfowl\| & $10-10^{2} \mathrm{~m}$ & R. J. Orth, unpublished data \\
\hline \multicolumn{3}{|l|}{ Reproductive shoot } \\
\hline \multirow[t]{13}{*}{ FloatingI } & not given & Ostenfeld (1908) \\
\hline & not given & Tutin (1938) \\
\hline & $10^{3} \mathrm{~m}$ & Setchell (1929) \\
\hline & not given & Churchill et al. (1978) \\
\hline & not given & De Cock $(1980)$ \\
\hline & $10^{3} \mathrm{~m}$ & Nienhuis (1983) \\
\hline & not given & Phillips and Backman (1983) \\
\hline & not given & Robertson and Mann (1984) \\
\hline & not given & Olesen and Sand-Jensen (1994) \\
\hline & $10^{3}-10^{4} \mathrm{~m}$ & Orth et al. (1994) \\
\hline & not given & Christensen et al. (1995) \\
\hline & $10^{2} \mathrm{~m}$ & Reusch (2001), and references therein \\
\hline & $10^{4} \mathrm{~m}$ & this study \\
\hline
\end{tabular}

\footnotetext{
$\dagger$ Direct release is defined as seed release from the attached reproductive shoot.

† Assumed to be tidal and wave-induced transport.

$\S$ Seeds can be transported on the water surface as a result of surface tension; bubble formation at the time of seed release has been observed to allow seeds to float to the water surface.

$\|$ Manipulative feeding experiment under laboratory conditions. Distance is inferred from gut retention time.

If Floating is defined as transport of reproductive shoots that have been fragmented off their anchorage in a bed.
}

bers 1999). However, some plant populations, regardless of life history, migrate more rapidly than predicted from their seed biology and ecology (e.g., Reid's paradox of rapid plant migration; Clark et al. 1998). The advent of landscape-scale observations (Pitelka and the Plant Migration Workshop Group 1997), detailed pollen analysis (Wilkinson 1997, 1999; and references within), and modeling exercises (e.g., Clark and Ji 1995, Clark 1998) have aided in understanding this paradox.

Most of the 58 species of seagrass, clonal marine angiosperms occurring on every continent except Antarctica (den Hartog 1970), grow and expand through both vegetative and sexual propagation. There is virtually no quantitative data on seagrass dispersal distance, for either vegetative shoots or seeds, especially long-distance dispersal $\left(>10^{2} \mathrm{~m}\right.$; Table 1$)$. While vegetative shoots with attached roots and rhizomes, if dislodged, have been observed floating at the water surface and can potentially disperse long distances, there is little evidence that these shoots can successfully reestablish naturally (Ewanchuk and Williams 1996; but see Clark 1989). Seeds also appear to have limited dispersal capabilities as they are either negatively buoyant (den Hartog 1970, Orth et al. 1994) or have structural adaptations (e.g., barbs, Turner 1985; seed membranes that enhance fall velocity, Orth 1999) that limit horizontal movement. Seeds of one species, eel- grass (Zostera marina L.), have been observed to be released from the flowering shoot with gas bubbles, which subsequently allow the seed to float on the water surface up to $10^{2} \mathrm{~m}$ (Churchill et al. 1985; M. C. Harwell and R. J. Orth, personal observation).

Most accounts of long-distance seagrass dispersal in the literature are qualitative, with observational reports dating back as far as $100 \mathrm{yr}$ ago, when Ostenfeld (1908) observed detached reproductive shoots of eelgrass in the detritus that was transported from established populations. However, it was not until 1929 that long-distance dispersal of eelgrass seeds via these floating reproductive shoots was hypothesized in the literature (Setchell 1929). Surprisingly, this process has been poorly quantified over the last $70 \mathrm{yr}$ (Table 1). One of the few studies on seagrass seed dispersal (calculated by multiplying mean current flow by a laboratory measurement of how long fruits floated in buckets filled with flowing seawater until seeds were released; Kaldy and Dunton 1999), reported that fruits with mature seeds of Thalassia testudinum may be able to disperse as far as $15 \mathrm{~km}$.

In the Chesapeake Bay area (including the coastal bays), distribution of eelgrass (Zostera marina $\mathrm{L}$.), the only seagrass in this region, is radically different from $70 \mathrm{yr}$ ago (Fig. 1). The combination of the wasting disease of the 1930s (Cottam and Munro 1954) and estuarine eutrophication and high sediment input into 

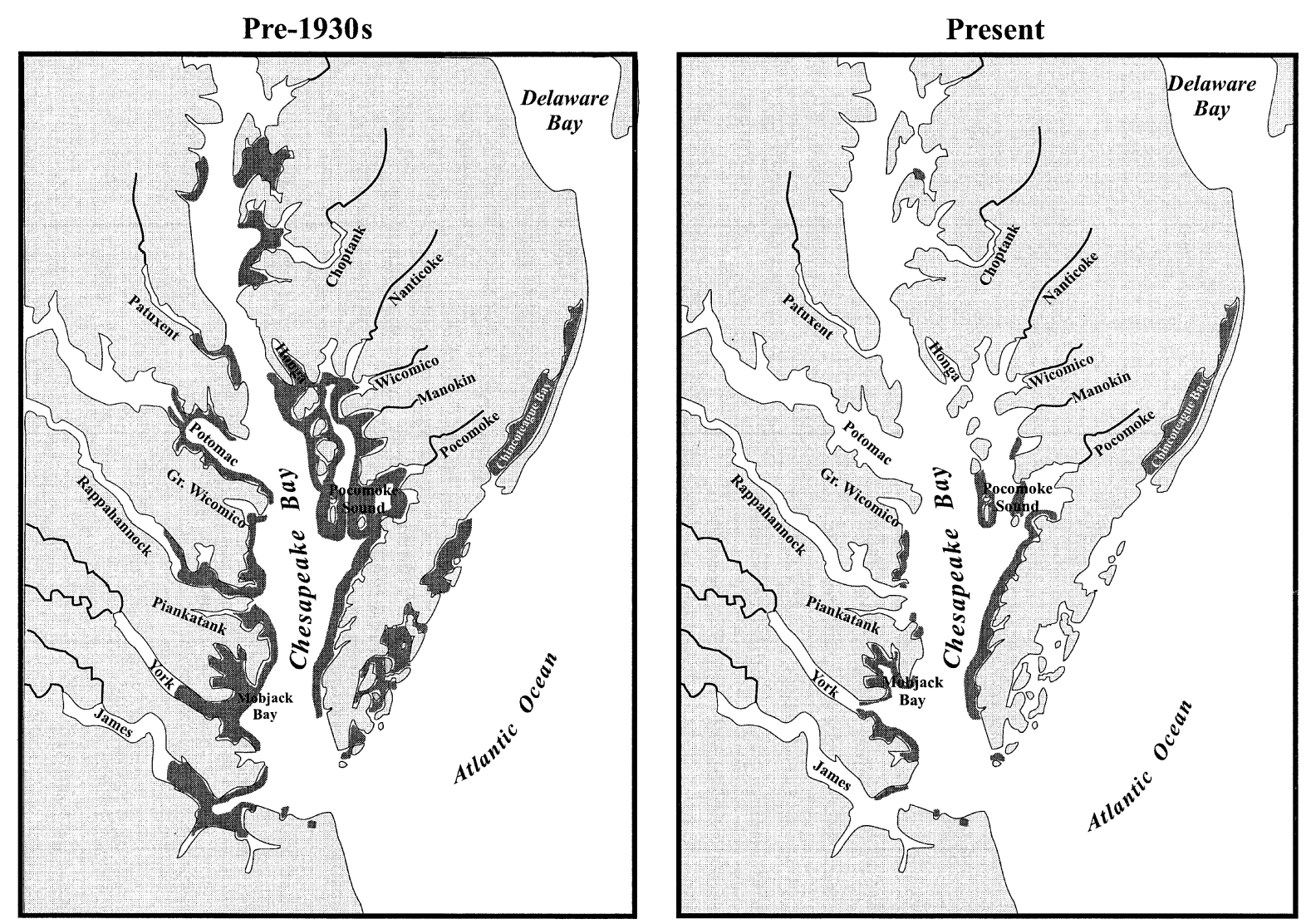

FIG. 1. Distribution of eelgrass (shaded areas) in Chesapeake Bay and coastal bays, pre-1930s and present.

the Bay in the 1960s and 1970s (Kemp et al. 1983, Orth and Moore 1983, 1984) have shifted eelgrass distribution down the mainstem and tributaries of the Chesapeake Bay (Fig. 1). Although some recovery has occurred, many areas remain devoid of vegetation or are only sparsely vegetated. Annual monitoring of seagrass in Chesapeake Bay and the coastal bays of the Delmarva Peninsula, from both aerial photography and intensive ground surveys (e.g., Orth et al. 1998), however, has identified new eelgrass patches distant from natural beds that could only have come from seeds. Reproductive propagation of eelgrass may explain patch growth and expansion better than vegetative growth; however, limited secondary seed dispersal (Table 1; Orth et al. 1994) does not account for new patch formation in areas distant $\left(>10^{3} \mathrm{~m}\right)$ from existing populations. Once on the sediment surface, eelgrass seeds do not move far (Phase II dispersal, $<10 \mathrm{~m}$; Orth et al. 1994) and can be influenced by surface microtopography and benthic fauna (Luckenbach and Orth 1999). No biological agents (e.g., waterfowl) in Chesapeake Bay have been shown to influence either primary (Phase I) or secondary (Phase II) seed dispersal, suggesting that long-distance dispersal of seeds via floating reproductive shoots may be the primary mechanism for the colonization events observed in the Bay.
Flowering in eelgrass populations in Chesapeake Bay begins in midwinter (January-February), with anthesis occurring in midspring (March-April) (Silberhorn et al. 1983). Unlike the strap-like vegetative shoots, the flowering shoot has a thin, round stem that is branched several times. Each branch (rhipidium) subsequently contains one or more inflorescence, with each inflorescence containing rows of male and female flowers (Fig. 2; De Cock 1980, 1981). Seeds are released from flowering shoots from mid-May to early June. Entire, or portions of, mature reproductive shoots can be easily detached in the later stages of flowering while seeds are being released (Silberhorn et al. 1983, Orth et al. 1994), and disperse from the bed either at the water surface or along the bottom via currents. Floating reproductive shoots can be observed within a window of several weeks, either individually or in windrows (i.e., rafts) (M. C. Harwell and R. J. Orth, unpublished data).

In this study, we investigated the long-distance dispersal potential of eelgrass in Chesapeake Bay through a combination of laboratory and field experiments and direct observations of recently colonized eelgrass beds to address the following questions: (1) Dispersal Potential: How long can floating reproductive shoots, with seeds, remain buoyant, and thus be transported from 


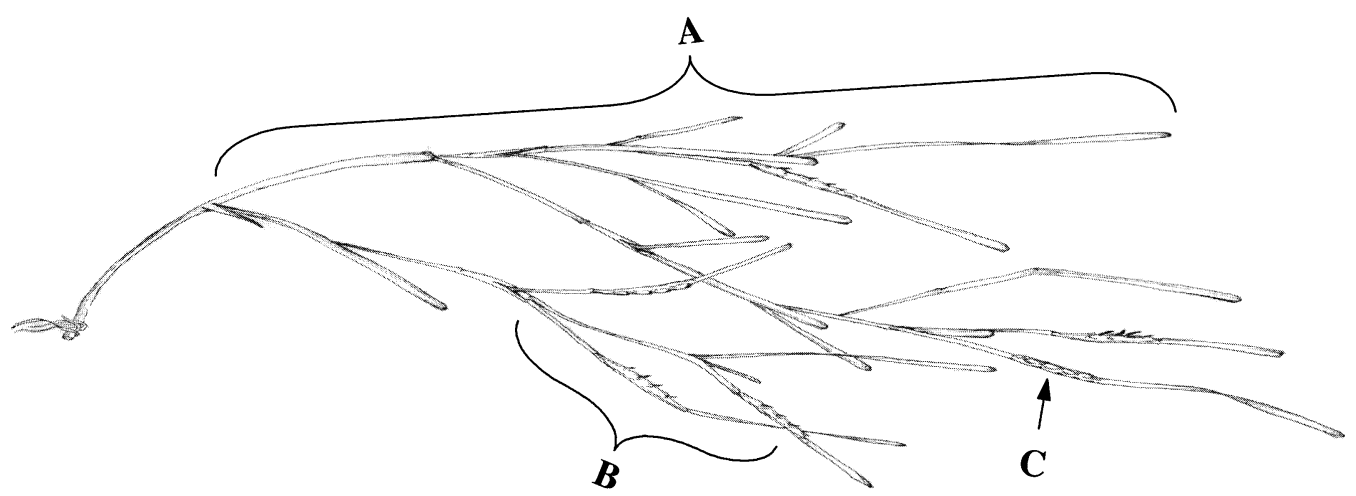

FIG. 2. Reproductive shoot of eelgrass showing (A) rhipidia, (B) inflorescence, and (C) seeds.

source populations? (2) Dispersal Distance: How far can floating reproductive shoots be transported?

\section{Methods \\ Dispersal potential}

We tested the potential for reproductive shoots with mature seeds to disperse over time by directly measuring how long seeds can be retained by detached shoots. We collected (by hand) whole reproductive shoots in late May, subsequent to pollination but before seed release when natural breaking is observed, from an eelgrass bed in the lower York River, Virginia. Forty-eight shoots were allowed to float on the water surface of a 3.8- $\mathrm{m}^{3}$ outdoor tank (with running air and water; following Orth et al. 1994). An additional 48 shoots were submerged to the bottom of the tank in a weighted mesh bag, designed to mimic reproductive shoots in the field that have become detached, but entrained within the canopy of surrounding eelgrass. Each set of 48 shoots were divided into four stages of retention time (1, 2, 3, $4 \mathrm{wk} ; n=12$ for each stage). Initial condition of the shoots was evaluated, including numbers of rhipidia, inflorescences, and viable seeds (cf., Fig. 2).

At weekly intervals for $4 \mathrm{wk}$, one batch of 12 shoots each from the floating and submerged experiments were sampled for visible shoot decomposition and seed retention. At each time interval, individual shoots were released in the York River at either the surface or the bottom of the water column (six shoots each), and the ability of a shoot to float for several minutes was qualitatively recorded as positive (i.e., floating at water surface), neutral (i.e., submersed but remaining in the water column), or negative (i.e., shoot sinks to bottom). For each experiment, one-way ANOVA was used to analyze proportion of seeds remaining (time: 1, 2, or $3 \mathrm{wk}$; note, there were no seeds or identifiable plant parts at week 4). Similar analyses were conducted for number of remaining inflorescences on each shoot.

\section{Dispersal distance}

We measured dispersal distance for floating reproductive shoots using two methods: (1) a direct measure of floating distance of reproductive shoots and an assessment of wind field properties during this time, and (2) an indirect measure of the minimum distance between newly created eelgrass patches and the nearest source (established bed) of reproductive shoots (an indirect measure).

The first method entailed a quantitative assessment of the presence of reproductive shoots in the detritus wrack along two different types of shorelines (Fig. 3): (1) a sandy beach with no nearby eelgrass beds (south Chesapeake Bay), and (2) a shoreline with dense fringing eelgrass beds that have been relatively stable for the last decade (Mobjack Bay). These surveys were conducted at the end of the eelgrass flowering season in this region (mid-June 1996) in order to obtain a snapshot of cumulative dispersal. A shoreline survey of south Chesapeake Bay was conducted by sampling at stations, predetermined by global positioning system (GPS) coordinates, every $100 \mathrm{~m}$ for $34 \mathrm{~km}$ (with two breaks by inlets) from Willoughby Spit $\left(36^{\circ} 58.15^{\prime} \mathrm{N}\right.$, $\left.76^{\circ} 17.6^{\prime} \mathrm{W}\right)$ to Virginia Beach $\left(35^{\circ} 53^{\prime} \mathrm{N}, 75^{\circ} 59.15^{\prime}\right.$ W) on the Atlantic Ocean (Fig. 3). The densest patch of wrackline detritus at each station was sampled with a $20 \mathrm{~cm}$ diameter ring. All the wrack material inside the ring was stored in a 4-L plastic bag and frozen until processed. As Mobjack Bay is characterized by erosional fringing marshes and large numbers of marsh creeks interdigitating the shoreline, five locations throughout Mobjack Bay were sampled with a $20 \mathrm{~cm}$ diameter ring ( $n=6$ at each location).

Variables measured for the shoreline survey of south Chesapeake Bay included: distance from nearest natural eelgrass bed; shoreline orientation (to the nearest $5^{\circ}$ ); wrackline orientation (to the nearest $5^{\circ}$ ); beach slope (categorical variable: shallow, steep, rocky); abundance of wrack on shore (categorical variable: none, trace, moderate, abundant); abundance of wrack in sample (proportion of bag full); number of reproductive shoot fragments; number of rhipidia; number of inflorescences; biomass of reproductive fragments; and number of seeds. Since seed viability cannot be measured in desiccated/frozen seeds using a tetrazo- 


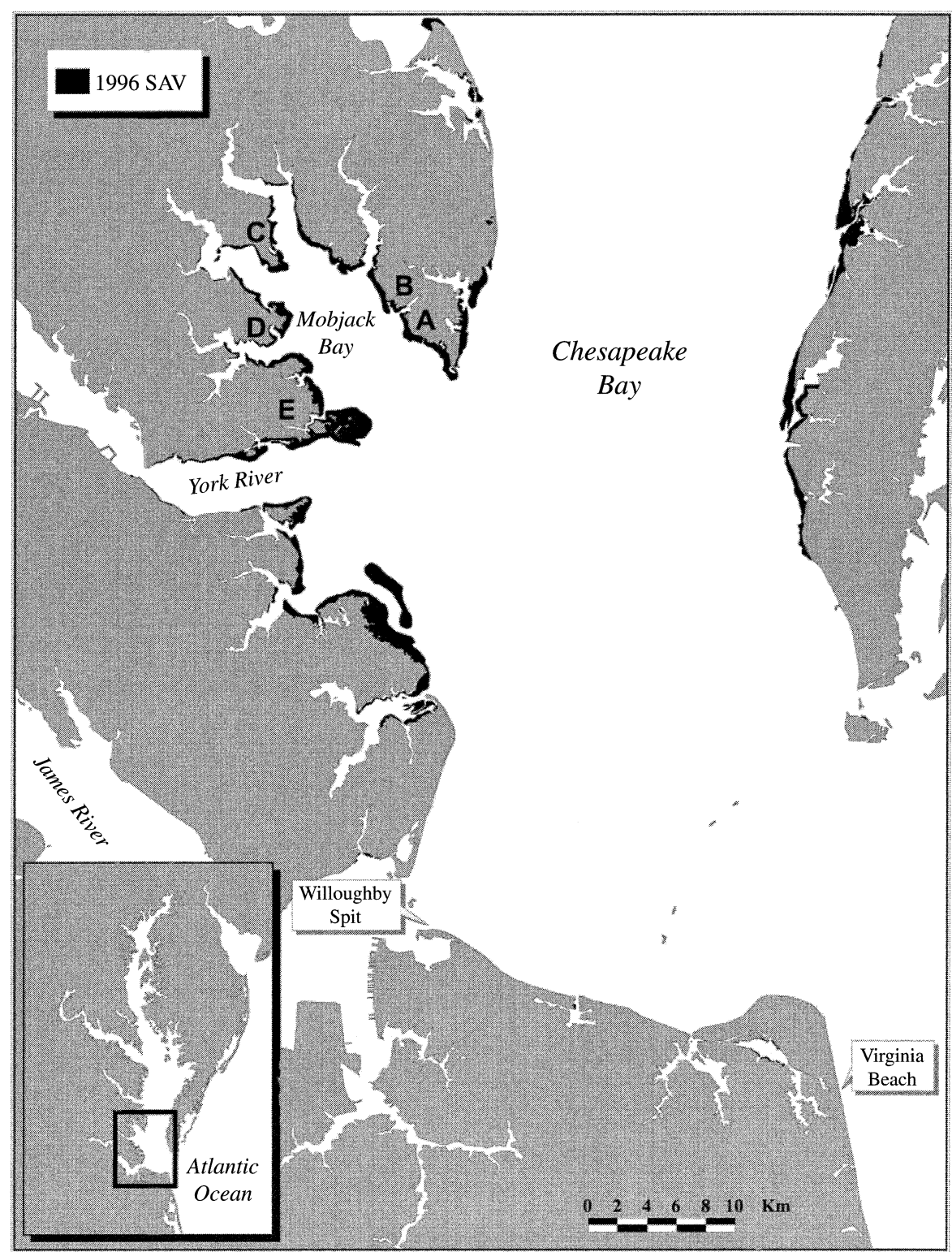

FIG. 3. Location of field sites in relation to the distribution of eelgrass in lower Chesapeake Bay. The shoreline survey of south Chesapeake Bay was conducted from Willoughby Spit to Virginia Beach. Sites A-E in Mobjack Bay indicate the field sites for the second part of the shoreline detritus-wrack sampling exercise. "SAV" denotes submerged aquatic vegetation; 1996 SAV refers to the distribution of SAV as mapped from an annual aerial monitoring program (Orth et al. 1997).

lium red vitality stain (M. C. Harwell, unpublished data), seeds were considered "viable" if they were full, rigid, and undamaged (following Harwell and Orth 1999). Multiple regression (backwards elimination) was used to describe the number of seeds (natural logtransformed to satisfy assumptions of homogeneity of variance; Zar 1996) found in the beach wrack as a function of all the biological and physical variables above, after first ensuring no spatial autocorrelation between samples. Pearson's correlation coefficients were calculated to determine the best plant metrics to describe seed abundance (Zar 1996).
We calculated hourly averaged wind field records for our study area for one month prior to the shoreline survey (VIMS Scientific Data Archive 1999), which we assume was the peak period of abundance of floating reproductive shoots, and decomposed them into N/S and E/W components. Combined with literaturebased calculations of surface currents for the mainstem of the middle and lower Chesapeake Bay, we calculated potential transport range for floating reproductive shoots.

The second method of studying dispersal distances of floating reproductive shoots entailed an analysis of 
a) Surface seeds

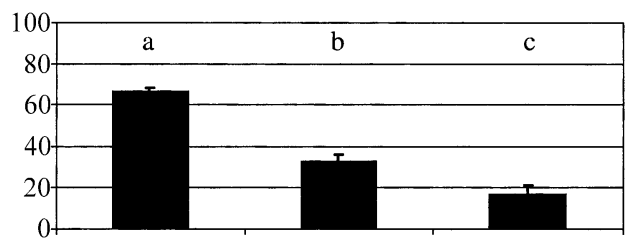

b) Bottom seeds

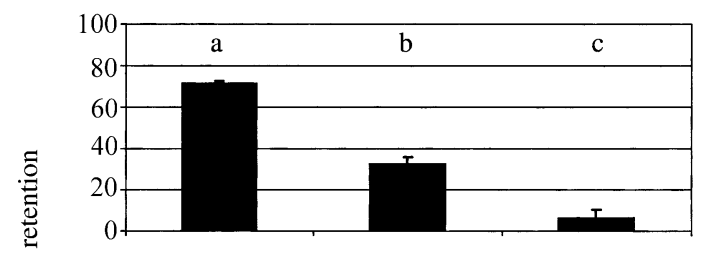

c) Surface inflorescences

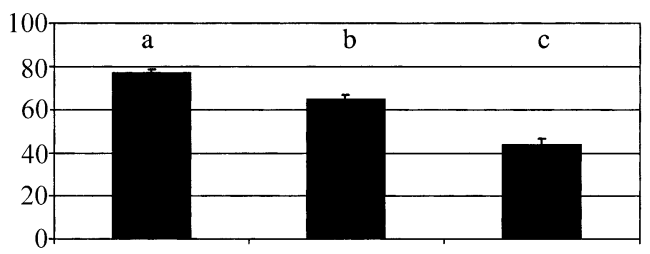

d) Bottom inflorescences

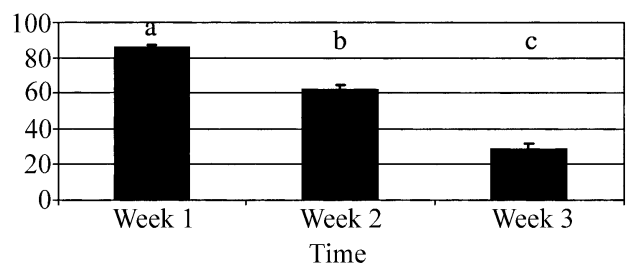

FIG. 4. Seed retention by shoots retained at the (a) surface and (b) bottom as a function of the time after a reproductive shoot has been removed from the parent bed. Inflorescence retention by shoots retained at the (c) surface and (d) bottom as a function of the time after a reproductive shoot has been removed from the parent bed. Different letters show differences between levels of time within each panel. Error bars represent $+1 \mathrm{SE}$.

different regions of the Chesapeake Bay and the coastal bays of the Delmarva Peninsula where we have observed colonizing eelgrass (patches generally $<4 \mathrm{~m}^{2}$ ) that could only have come from seeds transported in floating reproductive shoots. We specifically examined areas where eelgrass had totally declined and not been observed at that location for at least a decade since its decline in that area. This assessment was based on both an annual bay-wide survey, which has been conducted of populations of rooted submersed macrophytes using low-level vertical aerial photography since 1984 (e.g., Orth et al. 1998), and intensive ground surveys for species identification accompanying the annual mapping effort. All patches were field verified. The overwater distance between each patch and the nearest eel- grass bed that could have supplied floating reproductive shoots was calculated to the nearest $0.1 \mathrm{~km}$.

\section{RESULTS}

\section{Dispersal potential}

Reproductive shoots in the degradation experiments showed a clear loss of seeds over time (at least $98 \%$ of total variance explained by time for both surface and bottom retention experiments; surface $F_{2,32}=34.05$, bottom $F_{2,33}=64.88$; both $\left.P<0.0001\right)$. Similar differences were observed in seed loss over time between shoots retained at the surface and shoots retained at the bottom of the tank (Fig. 4a, b). After the 1st wk 70$75 \%$ of seeds remained, dropping to $8-15 \%$ by the 3 rd wk; all seeds were lost by the 4 th wk. This pattern was mirrored by inflorescence loss (at least $93 \%$ of total variance in inflorescence loss explained by time; surface $F_{2,33}=14.55$, bottom $F_{2,33}=46.92$; both $P<$ 0.0001 ; Fig. 4c, d). Buoyancy potential also degraded over time (Table 2); however, there was no observable (i.e., visible) difference in buoyancy potential between shoots released at surface vs. bottom regardless of surface or bottom retention experiment or degradation time.

\section{Dispersal distance}

Seeds in the eelgrass detritus were found along almost the entire 34-km shoreline of south Chesapeake Bay, including areas on the Atlantic Ocean in Virginia Beach (Fig. 5). One sample contained 20 reproductive fragments, while another sample had 16 seeds in one reproductive shoot fragment. Despite being fringed by eelgrass beds, few reproductive fragments were found in the wrackline of Mobjack Bay; only one fragment contained a seed (Table 3 ).

No spatial autocorrelation was found in the wrack data of south Chesapeake Bay (not shown). The number of seeds was described by the regression: $\ln ($ seeds $)=$ $0.84+0.57 \times \ln ($ no. reproductive shoot fragments $)+$ $1.91 \times$ biomass of reproductive shoot fragments $\left(r^{2}=\right.$ $0.592 ; P<0.001)$. Number of reproductive fragments was highly correlated with number of inflorescences (Pearson's correlation coefficient $=0.945$ ). Seed abundance was more strongly correlated with number of inflorescences (Pearson's correlation coefficient =

TABle 2. Potential for reproductive shoots to be exported out of a bed, as a function of time since removal from a bed; export potential of reproductive shoots with seeds is inferred.

\begin{tabular}{ccll}
\hline \hline Time & $\begin{array}{c}\text { Seed loss } \\
(\%)\end{array}$ & $\begin{array}{l}\text { Buoyancy } \\
\text { potential }\end{array}$ & $\begin{array}{c}\text { Export } \\
\text { potential }\end{array}$ \\
\hline Week 0 & 0 & positive & high \\
Week 1 & 25 & positive & high \\
Week 2 & 66 & neutral & moderate \\
Week 3 & 85 & negative & low \\
Week 4 & 100 & negative & low \\
\hline
\end{tabular}




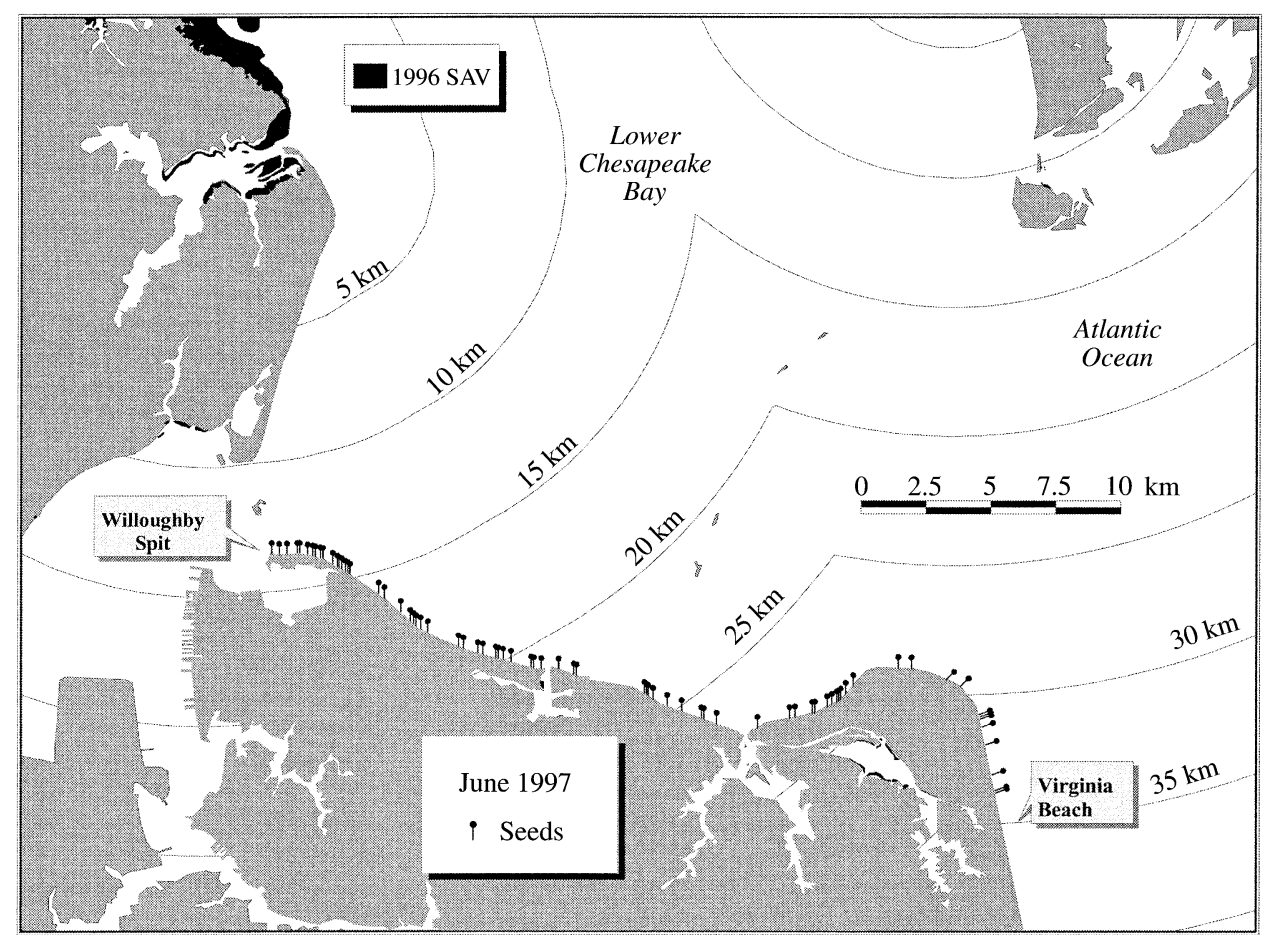

FIG. 5. South Chesapeake Bay map showing locations of seeds found and relative distance from nearest beds. Contour lines demarcate equidistant 5-km lines from eelgrass community distribution; 1996 SAV refers to the distribution of SAV as mapped from an annual aerial monitoring program (Orth et al. 1997).

0.775) than with number of rhipidia (Pearson's correlation coefficient $=0.658$ ). Site variables (distance from the nearest eelgrass bed, shoreline orientation, wrackline orientation, beach slope) were not significantly related to seed distribution; for example, distance from the nearest eelgrass bed (Fig. 6) was the first variable removed from the analysis. We note that there are several small, submerged aquatic vegetation beds in south Chesapeake Bay that were not included for dispersal distance measurements. These beds were very small and young (i.e., not mature enough to produce reproductive shoots comparable in abundance to larger, older beds), sparse or of mixed species composition, or very isolated by a long, narrow channel. They were therefore considered highly unlikely to contribute to the high abundance of eelgrass detritus we observed along almost the entire 34-km shoreline.

TABle 3. Mean number of reproductive fragments, inflorescences per reproductive fragment, and seeds found in the six samples collected from the eelgrass wrack at each of the five locations in Mobjack Bay.

\begin{tabular}{cccl}
\hline \hline Site & $\begin{array}{c}\text { Reproductive } \\
\text { fragments }\end{array}$ & $\begin{array}{c}\text { Inflorescences } \\
\text { per fragment }\end{array}$ & Seeds \\
\hline A & 0.333 & 3.5 & 0 \\
B & 0.333 & 2.0 & 0 \\
C & 0 & 0 & 0 \\
D & 0.167 & 3.0 & 0 \\
E & 0.667 & 3.0 & 0.167 \\
\hline
\end{tabular}

Winds averaged $7.7 \mathrm{~km} / \mathrm{h}$ (N/S component), and 10 $\mathrm{km} / \mathrm{h}$ (E/W component) during the month prior to the shoreline survey; however, there was no clear wind pattern during this period. There were 10 and $13 \mathrm{~d}$ that winds exceeded $10 \mathrm{~km} / \mathrm{h}(\mathrm{N} / \mathrm{S}$ and E/W components, respectively), and 1 and $4 \mathrm{~d}$ exceeding $15 \mathrm{~km} / \mathrm{h}(\mathrm{N} / \mathrm{S}$ and E/W components, respectively).

Filtering a time series of surface currents to reduce or remove high frequency tidal and meteorological influences, Goodrich and Blumberg (1991) calculated

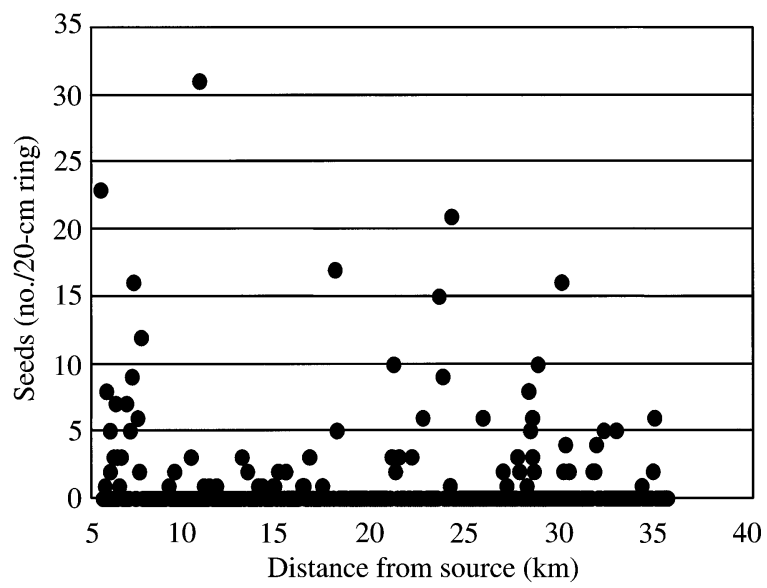

FIG. 6. Number of seeds per sample vs. distance from nearest Zostera marina beds. 


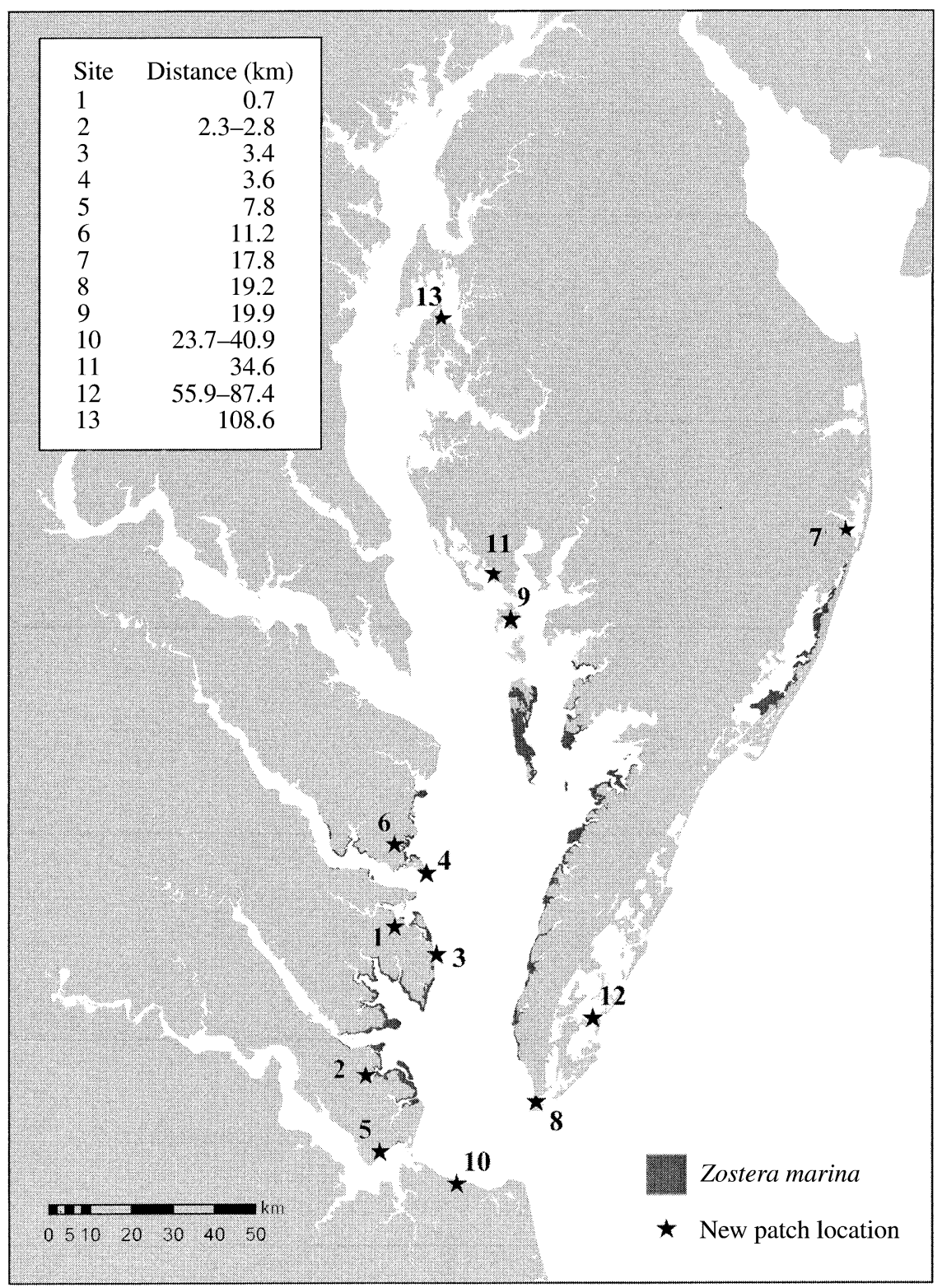

FIG. 7. Location of 13 recently established eelgrass populations in Chesapeake Bay and coastal bays in relation to the bay-wide distribution of eelgrass. The inset table shows minimum over-water distances from recently established populations to their nearest potential donor bed.

surface currents during an average flood tide in the mainstem of middle Chesapeake Bay between 5 and 7 $\mathrm{cm} / \mathrm{s}$. From this, we estimate that a passive particle at the surface could move $1-1.5 \mathrm{~km}$ in a 6 -h period (tides in our system are equal and semi-diurnal). Hood et al. (1999) described outgoing tidal velocities in the mainstem of lower Chesapeake Bay approaching $1 \mathrm{~m} / \mathrm{s}$, translating to a potential transport distance $\sim 22 \mathrm{~km}$ in a 6 -h ebb tide. Adding results from the wind field measurements (i.e., average N/S wind speed $=2.1 \mathrm{~m} / \mathrm{s}$; resulting surface current at $\sim 3 \%$ of the wind speed, Open University 1993) to the current flow calculations above, the potential transport range increases to 2.3$23 \mathrm{~km}$ within a 6 -h period.

Thirteen locations were identified with one or more small patches $\left(4 \mathrm{~m}^{2}\right.$ or less) of eelgrass conformed to our initial constraints (Fig. 7). Distance from nearest source ranged from $0.7 \mathrm{~km}$ at site 1 in the Piankatank River to $108.6 \mathrm{~km}$ at site 13 in Eastern Bay in uppermiddle Chesapeake Bay. This site was at the northern range of the historical distribution of eelgrass in Chesapeake Bay (Orth and Moore 1984). Three sites (2, 10, 12) were given two estimates as we assumed that those sites had the potential to be colonized by two different 
TABLE 4. Maximum dispersal distances as a function of dispersal mechanism reported for vascular plants with different plant types and habitats.

\begin{tabular}{|c|c|c|c|c|}
\hline Mechanism & Species & Plant type & Habitat & $\begin{array}{c}\text { Distance } \\
(\mathrm{km})\end{array}$ \\
\hline Water & $\begin{array}{l}\text { Cocos spp. } \\
\text { Zostera marina } \mathrm{L} . \\
\text { Avicennia marina } \\
\text { Zostera marina } \mathrm{L} . \\
\text { Thalassia testudinum Banks ex König }\end{array}$ & $\begin{array}{l}\text { tree } \\
\text { seagrass } \\
\text { tree } \\
\text { seagrass } \\
\text { seagrass }\end{array}$ & $\begin{array}{l}\text { coastline } \\
\text { marine } \\
\text { coastline } \\
\text { marine } \\
\text { marine }\end{array}$ & $\begin{array}{l}>100 \dagger \\
108.6 \ddagger \\
\sim 50 \S \\
34 \| \\
15 \pi\end{array}$ \\
\hline Bird & Pinus edulis Engelm. & tree & forest & $22 \#$ \\
\hline Wind & Epilobium angustifolium $\mathrm{L}$. & herb & field & $10 \#$ \\
\hline Adhesive & Achyranthes aspera L. & herb & field & 4.4\# \\
\hline
\end{tabular}

and discrete source beds. For example, potential source populations for Site 12 (South Bay), on the seaside of the lower Delmarva Peninsula, could have been the dense beds north in Chincoteague Bay (87.4 km distant) or the beds on the bayside of the lower Delmarva Peninsula at Cape Charles (55.9 km distant).

\section{Discussion}

The dispersal distances calculated from seeds found in the flowering shoots in the detrital wrack in our shoreline survey and from newly established patches distant from source populations, coupled to the length at which flowering shoots can remain buoyant with viable seeds, suggest that eelgrass has a dispersal strategy that maximizes colonization potential of distant, relatively noncompetitive habitats (the colonization hypothesis; Howe and Smallwood 1982). While individual seeds are negatively buoyant, lack dispersal enhancing characteristics, settle rapidly when released from the flowering shoot, and do not move far from where they settle on the sediment surface (Orth et al. 1994), long-distance dispersal from source populations is accomplished by the detached, buoyant flowering shoot. Seed dispersal by floating deteriorating shoots is enhanced by the morphology and degradation pattern of the reproductive shoot. As the shoot deteriorates over time, the stem of the shoot becomes neutrally (or negatively) buoyant while the inflorescences have slightly greater buoyancy potential. The shoot assumes a vertical, three-dimensional orientation in the water column, and finally a horizontal position on the sediment surface where it can either be transported along the bottom by currents or entrained on objects on the sediment surface that stick into the water column. For example, a common shallow-water, tube-building polychaete, Diopatra cuprea, cements reproductive shoots of eelgrass (carrying viable seeds) that have become entrained by its tube-caps into its tube walls, allowing for seeding of the area (Harwell and Orth 2001).

The dispersal distances reported here are among the highest reported in vascular plants, with a maximum dispersal $>1 \mathrm{~km}$ (Table 4). The dispersal distances for eelgrass are comparable in scale to mangroves and coconuts, considered classic examples of long-distance dispersers (Ward and Brookfield 1992, Clarke 1993), as the "maximum distances reported" for each were calculated by measuring the distance from the site of the dispersed propagule to the nearest potential source of that propagule.

Ruckelshaus (1996) found genetic neighborhood parameters for eelgrass to be among "the highest reported for plants and animals." This, when coupled to the long-distance dispersal potential for eelgrass we describe here, may have important ecological and evolutionary implications for the species. The ability of eelgrass to migrate rapidly and colonize distant habitats would be relevant following major climatic events, such as sea level changes from ice ages (sensu Reid's paradox of rapid plant migration; Clark et al. 1998). These two ecological aspects may be ultimately responsible for a low level of speciation given its worldwide distribution (den Hartog 1970).

We believe there are two primary physical mechanisms for moving the rafts of reproductive shoots noted not only in our system, but generally in other estuarine and coastal systems: water circulation (currents) and wind, which may operate in concert. In one tidal cycle alone, our calculation of potential dispersal, using a combination of tidal currents and wind influences (2.3$23 \mathrm{~km}$ in a 6-h period), could account for transport of rafting reproductive shoots to nine of our sites where new eelgrass patches were located (Fig. 7). We may be actually underestimating the potential dispersal distance of eelgrass reproductive shoots as movement in our system may be constrained by physical boundaries (e.g., shorelines). Although the direction of the current rotates throughout the tidal cycle in Chesapeake Bay (Hilder 1980), winds in the same direction of the water flow could also theoretically increase these distances. For example, Nienhuis (1983) documented a relationship between prevailing westerlies and a westward mi- 
gration of eelgrass in Lake Grevelingen, The Netherlands. Additionally, long-shore currents may play a critical role in keeping a reproductive fragment in nearshore waters for a significant portion of its dispersal, thus increasing the probability of seeds reaching new habitats at suitable water depths.

While biological vectors are important in seed dispersal and patch formation in terrestrial systems (Howe and Smallwood 1982, Chambers and McMahon 1994), we discount this mechanism in our system for vectors such as fish and waterfowl (see discussion in Orth et al. 1994). First, although there are some preliminary indications that eelgrass seeds may pass through the gut of mummichog (Fundulus heteroclitus) unharmed, the study was conducted under laboratory conditions with starved fish and eelgrass seeds presented in gelatin cubes (R. J. Orth, unpublished data). Further, we know of no published report of eelgrass seed found in gut contents of fish found in Chesapeake Bay. Second, while waterfowl have been reported to feed on eelgrass, reports including either reproductive shoots or seeds have come from other populations (e.g., Baldwin and Lovvorn 1994). Chesapeake Bay plays a critical role in the migratory pathway of waterfowl along the Atlantic coast; however, the timing of these migrations (approximately November to March) does not coincide with the flowering and seed release window of eelgrass in Chesapeake Bay and seed germination period in this region (early November) (Moore et al. 1993).

The establishment of new patches of eelgrass in many different regions of Chesapeake Bay approximately two decades following significant decline of this species (Orth and Moore 1983) supports the rapid colonization potential of this species. This short time frame is surprising in that we originally hypothesized a much longer time period for patch establishment because we assumed shorter dispersal distances. It is possible that even the distances we calculated here (1-109 $\mathrm{km}$ ) are actually conservative and that maximum dispersal may be on a scale approaching $10^{3} \mathrm{~km}$ or greater. The shoreline and tributaries of the Chesapeake Bay and coastal bays may be acting as barriers to dispersal. This may explain the approximately seven decades for a patch to form in the southern coastal bays where eelgrass has not been observed since 1933 (R. J. Orth, unpublished data).

While physical barriers may explain absence of eelgrass in other regions of some rivers in Chesapeake Bay that are within the envelope of dispersal distances that we have observed viable eelgrass patches, there are potential alternative hypotheses to explain patch absence. It is possible that: (1) patches have formed and disappeared because of post-settlement mortality (e.g., poor water quality [Dennison et al. 1993]) or intense biological perturbations such as cownose ray disturbance (Orth 1975); (2) there may be physical limitations of transporting a floating shoot to those sites (e.g., lack of appropriate prevailing winds or currents from established beds); (3) a longer time frame may be necessary for large-scale establishment than what we noted here; or (4) other patches are present but have yet to be discovered.

The lack of significant numbers of reproductive shoots in the detrital wrack of the Mobjack Bay compared to the shoreline of south Chesapeake Bay is initially puzzling given the entire Mobjack Bay shoreline is fringed with dense eelgrass beds. We suggest the strong vertical barrier of the erosional marsh edge, characteristic of much of the Mobjack Bay marshes, prevents floating shoots from being deposited on the marsh surface. Additionally, we hypothesize that the semi-enclosed circulation pattern of Mobjack Bay (cf., Hood et al. 1999: Fig. 3) maintains floating reproductive shoots within the nearshore shoal regions adjacent to the marsh edge where seeds are released. The fate of these seeds is unknown but may be important in maintaining or enhancing the existing beds in Mobjack Bay, especially if they remain in these nearshore shallow zones.

There have been previous reports of immigration of seagrass species into regions distant from sources; however, these have been attributed to human-intervention influences. Lipkin (1975) described the immigration of Halophila stipulaceae into the eastern Mediterranean as a result of ship transport of seeds after the breach of the Isthmus of Suez. Harrison and Bigley (1982) described the introduction of Zostera japonica into the coastal regions of the eastern Pacific Ocean as a consequence of increasing oyster imports from Japan (Z. japonica was used for packaging material). The rapid migration of $Z$. marina into Lake Grevelingen in the Netherlands appears to have been influenced by the human-caused closure of the former estuary (Nienhuis 1983).

Despite high genetic subdivision among populations in Chesapeake Bay (Williams and Orth 1998), we have demonstrated the potential for significant gene flow for subpopulations of eelgrass on an ecological time scale. Studying eelgrass beds of varying sizes, and under different environmental stresses (e.g., water quality), will be critical to identifying potential differences in the degree of reproductive effort and output of individual beds. The magnitude of reproductive effort and output may vary as a function of patch structure (Harwell 2000), water depth (Orth and Moore 1986), and interannual differences in flowering intensity (including pollination and fertilization; van Lent and Verschuure 1994). Modeling exercises of sexual reproduction (e.g., Bearlin et al. 1999, Harwell 2000) may identify critical aspects of the reproductive biology of eelgrass (e.g., source-sink dynamics; Pulliam and Danielson 1991) for further study, as well as explore issues of population response to sea-level rise. Future research on the metapopulation nature of eelgrass beds should also focus on identifying the magnitude of seed production that leaves a bed as well as investigating natural seedling 
recruitment at smaller spatial and longer temporal scales. Additionally, it may be important to understand if there is a minimum population size necessary for reproductive shoot export to be significant, or if one reproductive shoot from a single patch makes a difference. Overall, these efforts are important for future seagrass restoration questions, as efforts increase from small-scale to landscape-scale efforts.

\section{ACKNOWLEDGMENTS}

We thank C. E. Hayes for field assistance with the eelgrass detritus shoreline survey and help with Fig. 2, and D. J. Wilcox for GIS support in generating sampling locations and maps. Constructive criticism on this manuscript came from W. P. Cropper, J. E. Duffy, D. A. Evans, M. A. Harwell, and several anonymous reviewers. Funding for this project, in part, came from the Commonwealth of Virginia. Contribution number 2486 from the Virginia Institute of Marine Science, College of William and Mary.

\section{Literature Cited}

Baldwin, J. R., and J. R. Lovvorn. 1994. Expansion of seagrass habitat by the exotic Zostera japonica, and its use by dabbling ducks and brant in Boundary Bay, British Columbia. Marine Ecology Progress Series 103:119-127.

Bearlin, A. R., M. A. Burgman, and H. M. Regan. 1999. A stochastic model for seagrass (Zostera muelleri) in Port Phillip Bay, Victoria, Australia. Ecological Modelling 118: 131-148.

Cain, M. L., H. Damman, and A. Muir. 1998. Seed dispersal and the holocene migration of woodland herbs. Ecological Monographs 68:325-347.

Chambers, F. M. 1999. Comment on D. M. Wilkinson (1997). 'Plant colonization: are wind dispersed seeds really dispersed by birds at larger spatial and temporal scales?'. Journal of Biogeography 26:425-427.

Chambers, J. C., and J. A. MacMahon. 1994. A day in the life of a seed: movements and fates of seeds and their implications for natural and managed systems. Annual Review of Ecology and Systematics 25:263-292.

Christensen, P. B., O. Sortkjaer, and K. J. McGlathery. 1995. Transplantation of eelgrass. National Environmental Research Institute, Silkeborg, Denmark.

Churchill, A. C., A. E. Cok, and M. I. Riner. 1978. Stabilization of subtidal sediments by the transplantation of the seagrass Zostera marina L. New York Sea Grant Institute, NYSSGP-RS-78-15.

Churchill, A. C., G. Nieves, and A. H. Brenowitz. 1985. Floatation and dispersal of eelgrass seeds by gas bubbles. Estuaries 8:352-354.

Clark, J. S. 1998. Why trees migrate so fast: confronting theory with dispersal biology and the paleorecord. American Naturalist 152:204-224.

Clark, J. S., et al. 1998. Reid's paradox of rapid plant migration. BioScience 48:13-24.

Clark, J. S., and Y. Ji. 1995. Fecundity and dispersal in plant populations: implications for structure and diversity. American Naturalist 146:72-111.

Clark, P. A. 1989. Seagrass restoration: a non-destructive approach. Pages 57-70 in Proceedings of the 16th Annual Conference on Wetlands Restoration and Creation. St. Petersburg, Florida, USA.

Clarke, P. J. 1993. Dispersal of grey mangrove (Avicennia marina) propagules in southeastern Australia. Aquatic Botany 45:195-204.

Cottam, C., and D. A. Munro. 1954. Eelgrass status and environmental relations. Journal of Wildlife Management 18:449-460.
Cox, P. A., R. H. Laushman, and M. H. Ruckelshaus. 1992. Surface and subsurface pollination in the seagrass Zostera marina L. Botanical Journal of the Linnean Society 109: 281-291.

De Cock, A. W. A. M. 1980. Flowering, pollination and fruiting in Zostera marina L. Aquatic Botany 9:201-220.

De Cock, A. W. A. M. 1981. Development of the flowering shoot of Zostera marina L. under controlled conditions in comparison to the development in two different natural habitats in the Netherlands. Aquatic Botany 10:99-113.

den Hartog, C. 1970. The sea-grasses of the world. NorthHolland, Amsterdam, The Netherlands.

Dennison, W. C., R. J. Orth, K. A. Moore, J. Stevenson, V. Carter, S. Kollar, P. W. Bergstrom, and R. A. Batiuk. 1993. Assessing water quality with submersed aquatic vegetation. BioScience 43:86-94.

Ewanchuk, P. J., and S. L. Williams. 1996. Survival and reestablishment of vegetative fragments of eelgrass (Zostera marina). Canadian Journal of Botany 74:1584-1590.

Goodrich, D. M., and A. F. Blumberg. 1991. The fortnightly mean circulation of Chesapeake Bay. Estuarine, Coastal and Shelf Science 32:451-462.

Harrison, P. G., and R. E. Bigley. 1982. The recent introduction of the seagrass Zostera japonica Aschers. and Graebn. to the Pacific coast of North America. Canadian Journal of Fisheries and Aquatic Sciences 39:1642-1648.

Harwell, M. C. 2000. Ecological dispersal mechanisms, reproductive ecology, and the importance of scale in Zostera marina in Chesapeake Bay. Dissertation. College of William and Mary, Williamsburg, Virginia, USA.

Harwell, M. C., and R. J. Orth. 1999. Eelgrass (Zostera marina) seed protection for field experiments and implications for large-scale restoration. Aquatic Botany 64:51-61.

Harwell, M. C., and R. J. Orth. 2001. Influence of a tubedwelling polychaete on the dispersal of fragmented reproductive shoots of eelgrass. Aquatic Botany 70:1-7.

Hilder, F. A. 1980. Surface circulation and horizontal diffusion processes of the lower Chesapeake Bay. Dissertation. Old Dominion University, Norfolk, Virginia, USA.

Hood, R. R., H. V. Wang, J. E. Purcell, E. D. Houde, and L. W. Harding, Jr. 1999. Modeling particles and pelagic organisms in Chesapeake Bay: convergent features control plankton distributions. Journal of Geophysical Research 104(C1):1223-1243.

Howe, H. F., and J. Smallwood. 1982. Ecology of seed dispersal. Annual Review of Ecology and Systematics 13:201228.

Kaldy, J. E., and K. H. Dunton. 1999. Ontogenetic photosynthetic changes, dispersal and survival of Thalassia testudinum (turtle grass) seedlings in a sub-tropical lagoon. Journal of Experimental Marine Biology and Ecology 240: 193-212.

Kemp, W. M., R. R. Twilley, J. C. Stevenson, W. R. Boynton, and J. C. Means. 1983. The decline of submerged vascular plants in upper Chesapeake Bay: summary of results concerning possible causes. Marine Technology and Science Journal 17(2):78-89.

Lipkin, Y. 1975. Halophila stipulaceae, a review of a successful immigration. Aquatic Botany 1:203-215.

Luckenbach, M. W., and R. J. Orth. 1999. Effects of a depositfeeding invertebrate on the entrapment of Zostera marina L. seeds. Aquatic Botany 62:235-247.

Moloney, K. A., and S. A. Levin. 1996. The effects of disturbance architecture on landscape-level population dynamics. Ecology 77:375-394.

Moore, K. A., R. J. Orth, and J. F. Nowak. 1993. Environmental regulation of seed germination in Zostera marina L. (eelgrass) in Chesapeake Bay: effects of light, oxygen and sediment burial. Aquatic Botany 45:79-91. 
Nienhuis, P. H. 1983. Temporal and spatial patterns of eelgrass (Zostera marina L.) in a former estuary in the Netherlands, dominated by human activities. Marine Technology Society Journal 17(2):69-77.

Olesen, B., and K. Sand-Jensen. 1994. Patch dynamics of eelgrass Zostera marina. Marine Ecology Progress Series 106: $147-156$.

Open University. 1993. Ocean circulation. Pergamon Press, New York, New York, USA.

Orth, R. J. 1975. Destruction of eelgrass, Zostera marina, by the cownose ray, Rhinoptera bonasus, in the Chesapeake Bay. Chesapeake Science 16:205-208.

Orth, R. J. 1999. Settling rates of Posidonia coriacea seeds and Posidonia spp. seedling abundance off Rottnest Island, Perth, Western Australia. Pages 51-61 in D. I. Walker and F. E. Wells, editors. The seagrass flora and fauna of Rottnest Island, Western Australia. Western Australia Museum, Perth, Australia.

Orth, R. J., M. Luckenbach, and K. A. Moore. 1994. Seed dispersal in a marine macrophyte: implications for colonization and restoration. Ecology 75:1927-1939.

Orth, R. J., and K. A. Moore. 1983. Chesapeake Bay: an unprecedented decline in submerged aquatic vegetation. Science 222:51-53.

Orth, R. J., and K. A. Moore. 1984. Distribution and abundance of submerged aquatic vegetation in Chesapeake Bay: an historical perspective. Estuaries 7(4B):531-540.

Orth, R. J., and K. A. Moore. 1986. Seasonal and year-toyear variations in the growth of Zostera marina L. (eelgrass) in the lower Chesapeake Bay. Aquatic Botany 24: 335-341.

Orth, R. J., J. F. Nowak, D. J. Wilcox, J. R. Whiting, and L. S. Nagey. 1997. Distribution of submerged aquatic vegetation in the Chesapeake Bay and tributaries and Chincoteague Bay-1996. Final Report to U.S. Environmental Protection Agency. Chesapeake Bay Program Office, Annapolis, Maryland, USA.

Orth, R. J., J. F. Nowak, D. J. Wilcox, J. R. Whiting, and L. S. Nagey. 1998. Distribution of submerged aquatic vegetation in the Chesapeake Bay and tributaries and the coastal bays-1997. Grant no. CB993267-03-1. Final report to U.S. Environmental Protection Agency Chesapeake Bay Program, Annapolis, Maryland, USA.

Ostenfeld, C. H. 1908. On the ecology and distribution of the grass-wrack (Zostera marina) in Danish waters. Report of the Danish Biological Station 16:1-62.

Phillips, R. C., and T. W. Backman. 1983. Phenology and reproductive biology of eelgrass (Zostera marina L.) at Bahia Kino, Sea of Cortez, Mexico. Aquatic Botany 17: 85-90.

Pitelka, L. F., and The Plant Migration Workshop Group. 1997. Plant migration and climate change. American Scientist 85:464-473.
Pulliam, H. R., and B. J. Danielson. 1991. Sources, sinks, and habitat selection: a landscape perspective on population dynamics. American Naturalist 137(S):50-66.

Reusch, T. B. H. 2001. New markers-old questions: population genetics of seagrasses. Marine Ecology Progress Series 211:261-274.

Robertson, A. I., and K. H. Mann. 1984. Disturbance by ice and life-history adaptations of the seagrass Zostera marina. Marine Biology 80:131-141.

Ruckelshaus, M. H. 1994. Ecological and genetic factors affecting population structure in the marine angiosperm, Zostera marina L. Dissertation. University of Washington, Seattle, Washington, USA.

Ruckelshaus, M. H. 1996. Estimation of genetic neighborhood parameters from pollen and seed dispersal in the marine angiosperm Zostera marina L. Evolution 50:856-864.

Setchell, W. A. 1929. Morphological and phenological notes on Zostera marina L. University of California Publications in Botany 14(19):389-452.

Shafer, C. A. 1995. Values and shortcomings of small reserves. BioScience 45:80-88.

Silberhorn, G. M., R. J. Orth, and K. A. Moore. 1983. Anthesis and seed production in Zostera marina L. (eelgrass) from the Chesapeake Bay. Aquatic Botany 15:133-144.

Turner, T. 1985. Stability of rocky intertidal surfgrass beds: persistence, preemption, and recovery. Ecology 66:83-92.

Tutin, T. G. 1938. The autecology of Zostera marina in relation to its wasting disease. New Phytologist 37:50-71.

van der Pijl, L. 1982. Principles of dispersal in higher plants. Springer-Verlag, New York, New York, USA.

van Lent, F., and J. M. Verschuure. 1994. Intraspecific variability of Zostera marina L. (eelgrass) in the estuaries and lagoons of the southwestern Netherlands. I. Population dynamics. Aquatic Botany 48:31-58.

VIMS Scientific Data Archive. 1999. URL: 〈http://www. vims.edu/data_archive) Virginia Institute of Marine Science, College of William and Mary, Gloucester Point, Virginia, USA.

Ward, R. G., and M. Brookfield. 1992. The dispersal of the coconut: did it float or was it carried to Panama. Journal of Biogeography 19:467-480.

Wilkinson, D. M. 1997. Plant colonization: Are wind dispersed species really dispersed by birds at larger spatial and temporal scales? Journal of Biogeography 24:61-65.

Wilkinson, D. M. 1999. Birds and seed dispersal; a response to comments by F. M. Chambers. Journal of Biogeography 26:429-430.

Williams, S. L., and R. J. Orth. 1998. Genetic diversity and structure of natural and transplanted eelgrass populations in the Chesapeake Bay. Estuaries 21(1):118-128.

Zar, J. H. 1996. Biostatistical analysis. Third edition. Prentice Hall, Upper Saddle River, New Jersey, USA. 